\title{
Loss of Identity and Alienation in Jean Dominique Bauby's The Diving Bell and Lisa Genova's Left
}

\section{Neglected}

\section{Ghady Hamdy Ismail Ibrahim*}

\section{ghi11@fayoum.edu.eg}

Abstract

Impairment, whether gradual or traumatic, congenital or adventitious, can have an influence on one's own view of the world and his values. Disability has its impact on the disabled as it alienates him from people around him. The alienation that is caused by an impairment is undifferentiated from the one that happens because of other situations of social abuse. There is a relationship between the experience of living with an impairment and the disabled's selfperceptions. This experience helps in the formation of the disabled's identity. This identity has been enforced by the societal prejudices and the personal incapability. These conflicting feelings of alienation and loss of one's own identity are discussed in Lisa Genova's novel Left Neglected and Jean Dominique Bauby's disability memoir The Diving Bell. They show how a sudden accident causes a life-changing collision and how high- achieving people struggle to rebuild themselves and their lives.

Key words: Disability Studies, Psychology, loss of identity, and alienation.

* Demonstrator -English department -Faculty of Arts- Fayoum University. (Loss of Identity and Alienation in Jean Dominique ...) Ghady Hamdy 


\section{Objectives of the study}

This study aims at tackling the issue of the representation of disability in Jean Dominique Bauby's The Diving Bell and the Butterfly and Lisa Genova's Left Neglected. It attempts to provide a framework that explores the disabled individual's personal and realistic experience of living with a disability. It conducts a comparative psychological study on several disabled characters in the selected novels like Jean Bauby, the protagonist of The Diving Bell, Sarah Nickerson, the protagonist of Left Neglected.

\section{Method of Research}

The current study endeavors to apply disability theory and psychoanalysis to Jean Dominique Bauby's The Diving Bell and the Butterfly and Lisa Genova's Left Neglected. It focuses on applying loss of identity and alienation to the selected novels .

The alienation or the loss of identity happens when one becomes unable to recognize his body as his own. It happens when there is a separation between the person's own body and his mind as a result of the disability or the sudden occurrence of the accident. This study deals with the comparison of the loss of identity which happened to Jean Bauby and Sara Nickerson .

The research attempts to elaborate those psychological theories and shows how those theories are applied in the authors' narratives or reflected in the representation of the perspectives of the characters.

This study attempts to answer the following questions.

(Loss of Identity and Alienation in Jean Dominique ...) Ghady Hamdy 
Firstly, how does the shocking and unexpected occurrence of the accident cause a breach in a traumatic victim's experience of everything around him as represented in Genova's Left Neglected and Bauby's The Diving Bell? Secondly, how does a person feel after being deprived of what previously defined him/ her, including his/ her own voice and body? 
Major critics give various definitions of disability which all highlight negative aspects of the word/concept (John Swain, et al, Dan Goodley, Lenard Davis, and etc.). According to these definitions, the disabled person is immersed in failure and exclusion that locks him/her up inside him/herself and defines him/her basically in terms of his/her disability. A disabled person experiences a sense of loss over the abilities that injury or illness has destroyed. Disabilities exist when activities that are performed by people in their daily life (e.g., speaking, listening, walking) cannot be done in familiar ways.

Impairment, whether gradual or traumatic, congenital or adventitious, can have an influence on one's own view of the world and his values. James Romeis believes that disability results in alienation from society, the disabled's families, and even themselves (25). There is a relationship between the experience of living with an impairment and the disabled's self-perceptions, which helps in the formation of the disabled's identity.

The loss of one's ability to do things for him/herself and so the increasing dependency on other people is the most regretted loss which affects the disabled's identities. Persons with impairments live an arranged life. Decisions and activities are often made and selected for them. It is also hard for them to cope or overcome the limitations, whether they are emotional or practical, without obtaining knowledge and experience in confronting challenges or engaging activities. Rose Galvin's states:

(Loss of Identity and Alienation in Jean Dominique ...) Ghady Hamdy 
This dependency is much more than the physical reliance upon others because it begets a kind of unbalanced social relationship, which is considered as an obstruction more than the physical impairment itself. According to his research, the impaired people who had paid personal assistants feel more comfortable and have control of their lives, while those who relied on the sympathy and goodwill of others experience the feelings of shame and frustration because of their needs. (401)

What is it like to be conscious, but voiceless and paralyzed? What happens when one's body affects one's identity? The best known case is that of Jean Dominique Bauby who wrote The Diving Bell and the Bytterfly. Bauby, former editor of Elle, suffered a stroke to his brain stem that left him with Locked-in Syndrome. Barbara Wilson, et al stated that Locked-in Syndrome is a consequence of brain damage caused by a brain-stem lesion whose patients are unable to speak or move because of paralysis of nearly all muscles except for the eyes (526). It is a condition in which patients remain aware but are unable to communicate verbally or by gestures.

The Diving-Bell and the Butterfly, written by JeanDominique Bauby, narrates the author's experience of "locked-in syndrome" following a stroke in December 1995. This book has achieved remarkable success. It was translated from French into twenty-three languages. Its popularity may be related to the author's high profile as the editor of the

(Loss of Identity and Alienation in Jean Dominique ...) Ghady Hamdy 
French Elle magazine and to the horrific nature of the sudden turn in his life.

The popularity of the book may be because of the form of the story he tells, the way this disability account is recorded, and the tone and style with which the story is conveyed. The unheard voice of the paralyzed narrator reaches us despite almost unconquerable obstacles because of a code that makes it possible for him to communicate by blinking his one eyelid. The reader is drawn into Bauby's unfocused and sudden realization that no one can hear him and that there is something amiss. The reader hears his inner monologue and experiences Bauby's terror and claustrophobia. A man deprived of what previously defined him, including his own voice, succeeds to convey the unspeakable. He begins his journey of telling his novel from inside the prison of his own body. He employs his skills as a writer and produces a text that exists at the intersections of medicine and literature.

On Friday, $8^{\text {th }}$ of December, 1995, Jean was driving to pick up his son. While driving, he began to feel dizzy. He collapses in the back seat after pulling the car to the side of the road. While the driver speeds to the clinic, Bauby tries to say: "I try to say something like 'slow down. I'll get better... but no sound comes from my mouth and my head, no longer under my control, wobbles on my neck" (47).

When he awakens, he knows that he is in Room 119 of the Naval Hospital at Berck-sur-Mer. He is paralyzed from head to toe. He, his mind, is imprisoned inside his own body, unable to speak or move. He says:" blinking my left eyelid is my only means of communication" (10). He is locked into

(Loss of Identity and Alienation in Jean Dominique ...) Ghady Hamdy 
his body. By writing his memoir, using an accurate alphabetic system, he creates literary portals in which he connects the person he was before the accident to the person he has become.

The locked-in syndrome patients' personalities are locked into their motionless and powerless bodies. Patients like Jean-Dominique are mentally alert; they remember, understand, imagine and calculate, but their bodies are inflexible. Bauby presents himself to the readers in this memoir which offers a gateway into his loneliness, his hope, and his powerlessness. The novel deals with disability memoirs and offers a different way of reading first person narratives of disabled selfhood. As Ray Kent states in his article "Insights from Memoirs of Illness and Disability":

A new literary genre, known as illness narratives or disability memoirs, is accounts of living with or dying from an illness or disability... This literature complements... self-help manuals by explaining the human reaction to disease or disorder... Many textbooks and reference books have been written on the various afflictions to which flesh is heir... these sources frequently focus on the illness or disability, they tend to marginalize the person who actually has the medical condition. (22)

Disability memoir is like a life-writing in which the impaired person is capable of telling their own story, instead of letting it be told by caregivers or doctors. Bauby began to flex his freedom of thought in his memoir with the assistance

(Loss of Identity and Alienation in Jean Dominique ...) Ghady Hamdy 
of his speech therapist. He even learnt a new language, which is alphabet rearranged from the most frequently used letters to the least, to write this book. He presents two different selves, one before and one after the disability through his imagination. He depicts his shift from 'non-disabled' to 'disabled'. This literary work was written without even lifting a pen or opening a mouth and this deserves admiration.

The text is written letter by letter, so Bauby has enough time to select each word and its effect carefully. For him, the writing of his memoir is a two-stage process which relies on his own and the others' knowledge of the French language. Bauby's case is different from other writers who can write their own texts. He must prepare everything before dictating it to his interlocutor. He describes the process of dualdictation as follows:

You read off the alphabet... until, with the blink of my eye, I stop you at the letter to be noted. The maneuver is repeated for the letters that follow, so that fairly soon you have a whole word... That, at least, is the theory. In reality, all does not go well for some visitors. Because of the nervousness, impatience... performances vary in handling the code (which is what we call this method of transcribing my thoughts). (14)

This emphasizes the nature of his communication, which depends not only on Bauby, but also on his transcriber. It relies on Bauby's preparatory work and memory and the participation of his interlocutor. Some people are better than

(Loss of Identity and Alienation in Jean Dominique ...) Ghady Hamdy 
others at this kind of communication. He describes the varying abilities of people to end the words he starts.

Bauby's disability memoir deals with two different selves controlled by two different bodies, one before the stroke and one after it. It tackles two aspects of physical illness that help to inspire philosophical reflection. It describes alienation and freedom (Dudzinski 34, 35). The alienation occurs when the person is unable to recognize his body as his own and the freedom exists as a resistance. Bauby after the catastrophe is no longer himself. There is a separation between Bauby's own body and mind. From Denise Dudzinksi's point of view "The person knows oneself to be as a unified whole that resists distinctions among its component parts... It means to have the capacity to act and to feel that this action in one's body is an expression of oneself" (35). This means that the deliberate action is made available to us through our bodies.

Locked-in syndrome has affected Bauby, his body, his identity, his sense of himself and his being in the world. He no longer has control over his body or his actions. As Dudzinksi states, Richard Zaner writes "my body is an orientational locus"; he means that our bodies are our 'places' in the world and this place is taken for granted because human beings are occupied with activities and objects around them (36). So this means that one's orientational locus remains the same, his place or his body, but the ability for different actions like walking or running may be restricted by catastrophe such as locked-in syndrome or paralysis.

Bauby's disability is an obstacle against his wishes. He confesses: "I contemplate my books, piled up on the

(Loss of Identity and Alienation in Jean Dominique ...) Ghady Hamdy 
windowsill to constitute a small library: a rather useless one, for today no one will come to read them for me... A very black fly settles on my nose" (39). Also this appears when he feels his hands hurting, but he cannot tell, the simplest thing, whether they are hot or cold "My hand, lying on the yellow sheets, are hurting, although I can't tell if they are burning hot or ice cold... I instinctively stretch, my arms and legs moving only a fraction of an inch" (10). He describes a separation between himself and his body; before the accident it was so simple, swatting a fly, reaching for his books, or stretching his arms and legs, but after the accident it has become impossible that his body would respond to his desires.

The restrictions caused by Bauby's impairment contribute to alienation from himself and his own body. He considers his body as strange and uncontrolled. He considers himself to be seen by others as an object in their world to be noticed or ignored. The fact that other people can view us as they want can have an effect on our identity.

The effort that should be done by Bauby to regain himself is replaced by losing his old self and then discovering a new one. He gives up his old self through memories and gains the new one through imagination. Through his vivid memory and imagination, the butterfly, he creates a freedom that his motionless body, the diving bell, cannot actualize. He describes the diving bell as his physical body which locks him in.

Bauby also feels his body as inescapable:" Does the cosmos contain keys for opening up my diving bell?" (48) He

(Loss of Identity and Alienation in Jean Dominique ...) Ghady Hamdy 
is stuck in this body that cannot move anymore and this is clear when he says:" something like a giant invisible diving bell holds my whole body prisoner" (10). He wishes to escape the restrictions of his body. He realizes the limitations of his body and that his identity is entangled with these limitations. This is a tormenting experience because he still can remember when he was free to move and speak. He would do anything to get his freedom back "A currency strong enough to buy my freedom back?" (48).

Bauby describes the feeling of alienation when he feels estranged from his own children. His children, Theophile and Celeste, visit him on Father's Day at the hospital. While his son is playing hangman and his daughter is doing cartwheels on the beach, Bauby is torn between joy at seeing them moving and laughing or crying for his sufferings (30). He tries to communicate with his son, but his "communication system disqualifies repartee"(30). His grief surges over him and he expresses his sorrow when he says:

My son Theophile sits patiently waiting- and I, his father, have lost the simple right to ruffle his bristly hair, clasp his downy neck, hug his small, lithe, warm body tight against me. There are no words to express it. My condition is monstrous... horrible... I can take no more. Tears well and my throat emits a hoarse rattle that startles Theophile. Don't be scared little man. I love you. (30)

As stated by Dudzinski, "the way one is viewed by others has an influence on one's conception of himself" (38). Bauby

(Loss of Identity and Alienation in Jean Dominique ...) Ghady Hamdy 
is horrified and alienated from himself because he sees himself as other people see him. How he sees himself is influenced by how they see him. His understanding of their alienation from him strengthens his alienation from himself. He has the view, like most individuals without any personal experience with disability, that disability is a tragic and limiting condition that reduces his chances of fulfillment.

Besides Bauby's inability to speak or move, he cannot frown, laugh, smile or squeeze someone's hand. His selfexpression can be tormenting and torturous. His vivid prestroke identity is replaced by motionless and limp character. After waking from a two-month coma, Bauby describes the test of 'the wheelchair':

I had graduated from being a patient whose prognosis was uncertain to an official quadriplegic... my caretakers made me travel the length and breadth of the hospital floor, to make certain that the seated position did not trigger uncontrollable spasms, but I was too devastated by this brutal down-grading of my future hopes to take much notice. (11)

This shows Bauby's conception of himself as broken. His physical condition first needed him to regain himself, but now promises vain physical effort. Things which before required no effort at all like eating, now not only require planning and effort, but also exclude taste, mastication, or swallowing. He is fed by a tube. As it is stated by Thompson:

When disability occurs suddenly, as in the case for Bauby, there is an unexpected jolt in subject

(Loss of Identity and Alienation in Jean Dominique ...) Ghady Hamdy 
position: by transitioning from the subjectposition of 'non-disabled' to that of 'disabled', the self temporarily becomes other until the new subject-position can be assimilated. (3)

Bauby's stunned reaction to the news that he is not going to recover from what he had supposed was a temporary impairment, is the catalyst for the transformation in his subject-position which will be his subject in his disability memoir. After the occupational therapist says to him that he can handle the wheelchair, he says:" to my ears it had the ring of a life sentence. In one flash I saw the frightening truth. It was as blinding as an atomic explosion" (11).

His sense of humor sometimes relieves depression. His self-mocking demonstrates that he does not always see his impairment as a tragedy. He says:" If I must drool, I may as well drool on cashmere" (13). As his aide, Claude, pushes his wheelchair, he catches the smell of French fries which makes his nostrils shake with pleasure: "My nostrils quiver with pleasure as they inhale a robust odor - intoxicating to me" (34). He loves luxury and savors imaginary meals. He says:

For pleasure, I have to turn to the vivid memory of tastes and smells... Now I cultivate the art of simmering memories... Depending on my mood, I treat myself to a dozen snails, a plate of Alsatian sausage... or else I savor a simple softboiled egg... What a banquet! (19)

What he lacks is his freedom to do physical actions. He cannot savor eggs instead of sausage. In reality, he can savor neither of them! He cannot hug his kids or play with them.

(Loss of Identity and Alienation in Jean Dominique ...) Ghady Hamdy 
For him, these are just unattainable wishes, not options. He no longer has options in choosing his friends, with whom he spends or does not spend time. He cannot respond to his father's grief or his daughter's cartwheels. His response is not even noticed by those he wishes to communicate with.

In the week of the stroke, Bauby visits his aged father. He describes that locked-in syndrome is more than just an illness; it is the helplessness and the isolation people feel at times. His voice emphasizes the life that is inside a man whose body seems to be dead. He describes being locked-in his own body and his father being locked-in his own apartment because of his body:

We have not seen each other since. I cannot quit my seaside confinement. And he can no longer descend the magnificent staircase of his apartment building on his ninety-two-year-old legs. We are both locked-in cases, each in his own ways: myself in my carcass, my father in his fourth floor apartment... it cannot be easy for him to speak to a son who... will never reply. (21)

From Dudzinski's point of view, the tragic consequence of locked-in syndrome in Bauby's life is the availability, which accompanies the physical powerlessness (43). His condition makes him available to anyone who can and would walk into his room. Bauby confesses:

One day, for example, I can find it amusing, in my forty-fifth year, to be cleaned up and turned over, to have my bottom wiped and swaddled

(Loss of Identity and Alienation in Jean Dominique ...) Ghady Hamdy 
like a newborn's... But the next day, the same procedure seems to me unbearably sad, and a tear rolls down through the lather a nurse's aide spreads over my cheeks. And my weekly bath plunged me simultaneously into distress and happiness. The delectable moment when I sink into the tub is quickly followed by nostalgia for ... the joy of my previous life. (13)

Here Bauby expresses his chaotic emotions during bathing. His body is not his property anymore. It shows the transition from the able-bodied Bauby to Bauby the prisoner. He describes being locked-in his own body and the feelings of helplessness and powerlessness he endures. These shifting emotional states, as stated by Helle Mathiasen, become manifest in the style of his book (829).

Bauby calls the hospital's other patients as "tourists" (18). He calls them like this because of their temporary presence in the hospital, in contrast to his long-term residence. He finds his inability to talk and merge with them disturbing. While they are happy to talk to each other, they are unable even to meet Bauby's eye:

People laugh, joke, call out. I would like to be part of all this hilarity, but as soon as I direct my one eye toward them, the youn man, the grandmother, and the homeless man turn away, feeling the sudden need to study the ceiling smoke detector. The "tourists" must be very worried about fire. (18) 
The "tourists" reaction towards Bauby exemplifies the society's attitude to the disabled. It shows how the society tends to assume that the impairment or the illness turns impaired people into passive recipients. This interior monologue by Bauby shows that some of the difficulties he faces are caused by his physical state and the inability of the people around him to treat him in sensitive ways. The situation offers people's failure to realize his attempts at communication, to realize his selfhood, to consider him as an individual, and to value his embodiment. People's assumptions that Bauby's paralysis has stolen his selfhood from him must be hurtful to him.

Elle magazine stresses the importance of health, beauty, and the physical appearance, but Bauby after the stroke separates himself from these corporeal constraints. There is a gap between how he feels and how he looks. When he was the editor-in-chief of Elle magazine, his appearance was not a problem for the reflection of his inner self. But after the stroke, his physical identity no longer suits his mind's picture of himself. Most people assume that this physical identity is the reflection of him.

Bauby constructs a liberating fantasy world in which he is not constrained by his own impairment or by the society's expectations. He uses his imagination to overcome his situation and he rejects the timetables and the rules of the hospital to get a more creative reality:

The lighthouse and I remain in constant touch, and I often call on it by having myself wheeled to Cinecittà, a region essential to my imaginary

(Loss of Identity and Alienation in Jean Dominique ...) Ghady Hamdy 
geography of the hospital... I could spend whole days at Cinecittà. There, I am the greatest director of all time... I am the hero of Godard's Pierrot le Fou. (17)

The south-facing terrace of Sorrel Ward becomes "Cinecittà", which is a charming movie set that allows him to turn himself into "the greatest director of all times"(17). Bauby's creative imagination and his capacity to cast in different roles remind people, who associate paralysis with passivity, that although the body is powerless, the mind can be creative and imaginative.

Bauby's body has become a restrictive inescapable diving bell that imprisons him and drags him to the ocean of desperation and despair. He wishes to escape the restrictions of his body, but then he realizes his body's limitations. It is a tragedy to be conscious, but paralyzed and voiceless. It is hard to have a personality that is trapped into a powerless and motionless body. On the other hand, his mind is free and light as a butterfly. It is Bauby's memory and imagination, his butterfly, which allows him to escape the diving bell. This complicated relationship with his body becomes the topic of his narrative because this memoir is the gateway into his hope, his powerlessness, and his loneliness. Sometimes he is flying and at other times he is sinking, but he is always reacting to this relationship and trying to express it.

Another case when a sudden accident causes a lifechanging collision can be found in Left Neglected by Lisa Genova. Left Neglected was published in 2011. It revolves around a high-achieving woman, Sarah Nickerson, who

(Loss of Identity and Alienation in Jean Dominique ...) Ghady Hamdy 
suffers a traumatic brain injury and her struggles to rebuild her life. Sarah is a woman in her mid-30s and she works as the vice president of human resources at Berkley Consulting. She wakes up to find herself involved in a severe car accident while driving to work and trying to make a phone call which causes her a traumatic brain injury which completely erases the left side of her world.

Lisa Genova is a novelist-neuroscientist who can pair her knowledge of the workings of the brain with her ability to depict the human experience of having a brain injury. In her novel Left Neglected, Genova turns her concentration to a lesser- known impairment called 'left neglect'. The novel tells about a rare medical condition and the story of a character that rises above a tragedy to find her appreciation for life.

When Sarah, the protagonist, regains her consciousness eight days later, the doctors know that she has left neglect. 'Left Neglect' or hemispatial neglect is a neurological syndrome that occurs because of damage to the right hemisphere of the brain, such as might follow a traumatic brain injury (Left Neglected 359). The patients with left neglect are not blind, but their brains ignore any information on the left side of their own bodies or the left side of the world (359). It means that their brain doesn't register that there are things that exist on their left side; for them there is no left. Left is like a black hole for them (123).

The person fails to recognize the left side of everything, but it is a perception problem not a vision problem. The body is physically healed, but the brain failed to recognize the

(Loss of Identity and Alienation in Jean Dominique ...) Ghady Hamdy 
improvement. The result is that the person will continue to experience symptoms that do not help his/ her wellbeing. This is because his/her brain is responding to an impairment, illness, or trauma that is not even present. It can lead to problems with their mobility because they have unawareness of their left extremities. It causes problems in any task which uses bilateral skills.

The narrator, who is also the major character, wants to say that when she was forced by her medical condition to neglect whatever exists on her left side, she was neglected because she was no longer as important, active, useful or smart as she has been before the accident. 'Left neglect' is a name that suggests no doer of the action because of her deficient mind, but 'Left Neglected', in the passive voice, makes her an object and leaves the reader to think about the subject. Sara struggles to search and find answers about her forgotten past and uncertain future. She struggles to return back to her overscheduled life, but she had to face new things like her son's Attention Deficit Hyperactivity Disorder (ADHD), the return of her estranged mother, and her own impairment.

Sarah deals with two different selves controlled by two different bodies, one before her accident and one after it. She cannot recognize her body as her own. The alienation occurs when the person is unable to recognize his/her body as his/her own. Sarah after the accident is no longer herself. There is a separation between her body and mind. She might not believe that some parts of her body belong to her. The doctor says:

(Loss of Identity and Alienation in Jean Dominique ...) Ghady Hamdy 
She has Left Neglect. It's a pretty common condition for patients who've suffered damage to the right-hemisphere, usually from hemorrhage or stroke. Her brain isn't paying attention to anything on her left.' Left' doesn't exist to her... It's not there for her. She won't notice you if you're standing to her left, she won't touch the food on her left side of the plate, and she might not even believe that her left arm and leg belong to her... to her... everything is normal. (94)

She is unaware of her unawareness. She is unaware that the left side of everything is missing. She lost the ability to know that the actions by her body are expression of herself, she says:" of course I know I have a left hand... where is my left hand? I have no idea. Oh my God... Bob, I know I have a left hand, but I have no idea where it is." $(94,95)$. This appears clearly when she says:" I'm missing a whole continent of experience, and I'm not even aware of it. I'm not aware that I'm not noticing the left half of my face... To me, nothing is missing (147).

The very first step of Sarah's recovery is to become aware of her awareness. She must keep reminding herself that her brain thinks it is observing to all of everything, but in reality, it is observing the right half and nothing on the left. She thinks she must have an inner babysitter to lead every move:" Hey there, Sarah, you think you're seeing your whole face, but you're actually only paying attention to the right side.

(Loss of Identity and Alienation in Jean Dominique ...) Ghady Hamdy 
There's another half there. It's called the left. Honest to God"(147).

The second step, after becoming aware of her awareness, is to stretch her imagination and focus to find the other missing half. The process of seeing the world as a whole that used to be automatic is now a persistent and thoughtful process. She says:" Look left. Scan left. Go left. It sounds simple enough, but now how do I look, scan, or to go to a place that doesn't exist to my mind? ... My new mind is broken and doesn't give a whack about the left"(148).

Sarah is living a very busy life. She and her husband have ambitious jobs. She is smart, powerful, and insistent to achieve much in her life. If she had any thoughts to slow down in her life, she would shut them up and send them back to their place. After the accident, she must learn to adapt to her impairment and evaluate her priorities in life. She carries readers along on her physical and mental transformations. She learns that sometimes having everything can lead to catastrophic consequences. She says:

I think some small part of me knew I was living an unsustainable life... Every now and then, it would whisper, Sarah... You can't continue like this. But the rest of me, powerful... wasn't hearing a word of it. If, once in a while these kinds of thoughts did manage to wiggle into my consciousness, I shushed them... I guess I needed something less fleeting and more concrete. Like a traumatic smack to the head. (17)

(Loss of Identity and Alienation in Jean Dominique ...) Ghady Hamdy 
When meditation is added to her list of rehabilitation techniques, it is odd for her. She does not have any inclination to meditate because meditation is like doing nothing and she does not do nothing. She used to accumulate every second of her day with something that can be done. She says:

Have five minutes? Send an email. Read the school notices. Throw in a load of laundry... Got ten? Return a phone call. Outline the agenda for a meeting... Sit with my eyes closed and breathe without planning, organizing, or accomplishing anything? I don't think so (163).

According to her, anyone still standing at Berkley after ten years becomes a partner and they are almost men and divorced. She is one of the only women who reached this level. She does not want to let down any of her partners, so she never admits having too many tasks. For her, there are some completely full days when there is no time for lunch or no room for error. She says:" On those days, I feel like a balloon blown to capacity, ready to burst... when I feel like I'm about to explode... I lock my office door... and let myself cry for five minutes" $(49,50)$.

'Left neglect' has affected Sarah, her body, her identity, and her sense of herself. She no longer has control over her body or her actions. She no longer can hug her children with two hands, she cannot see all of her husband, and she cannot get back to work with reading only half of an Excel spreadsheet. It is like that her impairment is an obstacle against her wishes. There is a separation between herself and

(Loss of Identity and Alienation in Jean Dominique ...) Ghady Hamdy 
her body. Before the accident it was so simple, finishing her plate, hugging her children, doing her work, and taking care of her children and her husband, but after the accident it has become impossible that her body would respond easily to her smallest desires. She expresses:

I want to draw both of Lucy's eyes. I want to hug Charlie with two hands, kiss both of Linus's feet, and see all of Bob. And I can't get away with reading only the right half of an Excel spreadsheet. I need my brain to see the left again. (100)

Sarah's accident lands her in a rehabilitation facility, where she struggles to deal with her new limitations: she cannot walk on her own without a cane; she needs help with brushing her teeth; she cannot get dressed without assistance, and she cannot even release the spoon in her left hand without coaching. Driving is impossible, as is getting back to her job any time soon. Beyond these physical obstacles lies the voice in her head that keeps inquiring," What if the rehabilitation doesn't work? What if this never goes away? What if I can't go back to work? I can't live like this" (118). Although she achieves some progress, recovery is going to take much longer than she thought. No matter how hard she tries, she cannot accelerate the process.

Sarah's world before the accident was meetings, deadlines, emails, reports, her husband, and the kids. Even during the accident all she cares about is that "someone should tell work where I am and what's happened" (84).

(Loss of Identity and Alienation in Jean Dominique ...) Ghady Hamdy 
After two weeks from the accident, she is still immersed in her work and emails:

I haven't checked my email since I've been here... My heart races when I think about it. My inbox must have a thousand emails waiting for me... I need to get back to make sure we get the right people and place them where they'll best fit. (103)

These restrictions caused by Sarah's Impairment contribute to alienation from her body. She considers her body as strange. She cannot recognize her body as her own. When life begins to return to her left hand, everyone sees this as a positive sign, but Sarah has another opinion. She says: "to me it's a freaky symptom because it feels like someone other than me the puppeteer" (271). Even walking with a left leg, that according to her," fades in and out of existence" is difficult and frustrating (176). She cannot guess when this leg is going to touch the floor and she ends up causing something painful and weird to herself. The alienation from her body appears clearly when Martha, her physical therapist, and her mother were rubbing her arms with a washcloth. She says:

It's almost as if I'm watching my mother wash someone else's arm. It's as if the cloth against my skin is telling my brain, Feel that? That's your left shoulder. Feel that? That's your left elbow. But another part of my brain... keeps retorting, Ignore this foolishness! You don't have a left anything! There is no left! (110) 
The alienation occurs when the person is unable to recognize his/her body as his/her own. As it is mentioned previously, Dudzinksi states that "The person knows oneself to be as a unified whole that resists distinctions among its component parts... It means to have the capacity to act and to feel that this action in one's body is an expression of oneself" (35). After the accident, Sarah lost her capacity to feel herself as an integrated whole. Her brain is unable to recognize her whole body. She thinks that she is capable of doing things on her own because she feels normal. For her, nothing is missing. But in reality, she is paying attention to only half of the things. For example, when she tries to use the bathroom on her own, she says:

I suddenly feel like I'm perfectly capable of this. Maybe it's because I feel normal... I don't feel like I'm paying attention to only half of me or half of my mother or half of the bathroom. I don't feel like anything's missing. Until I take that first left step... I go crashing to the floor. (111)

This lack of control is a severe problem for someone who likes being in charge like Sarah who considered herself as a "multitasking genius" (163). It is even worse when she requires assistance with mundane tasks, like flossing her teeth or getting dressed. For her, 'Left neglected' is more than just an illness; it is the helplessness she feels at times. She describes the insistent nagging voice in her head that tells her about the things she needs to do:

(Loss of Identity and Alienation in Jean Dominique ...) Ghady Hamdy 
I can still hear the nagging list that was playing in my head just before the accident. You need to call Harvard before noon, you need to start year-end performance reviews, you need to finalize the B-school training program for science associates... . (134)

After the accident, she begins to describe the new voices in her head. The voice in her head begins delivering a different kind of laundry list:

"You need to get better, you need to get out of here, you need to go home, you need to go back to work..."(135). This voice makes her aware of another scared voice, which repeats the disturbing question of "What happens if I don't get better?"(136)

According to Sarah, the strangest thing for her is "seeing herself sitting in a wheelchair"(148). She does not feel handicapped because nothing is missing for her. She is not paralyzed; her left side can move and the muscles and nerves are all ready for the instruction "Come on, Sarah, press the A button"(148). For her, using a wheelchair and accepting the situation are synonyms for giving up. She keeps reminding herself "I'm not giving up, I tell my conflicted self. Sometimes I'm just too exhausted to fight" (159).

Later on Sarah's impairment has become an opportunity for personal growth and positive changes in her life like trying to come to terms with her past and her broken relationship with her mother. She was given a traumatic opportunity to know what is really important in life and where her priorities lie. She earned her peace of mind by the

(Loss of Identity and Alienation in Jean Dominique ...) Ghady Hamdy 
existence of her family around her and their support. She has been given the opportunity to think about all the love and help she has received. Her days in the rehab facility make her acknowledge what is positive about her condition; she could have easily died in that accident, in surgery, or after surgery. On her last day in the gym, she sees the picture on the poster differently. She says:

The picture on the poster is of two hands, not one... The hands are clasped together. Holding hands. And the word above the hands in red letters isn't Attitude. The word... is Gratitude... I think about Heidi and Bob and my kids and even Martha and my mother and all the help and love I've been given and all I have... Thank you for sharing this with me (186).

In conclusion, Impairment can have a great effect on one's own view of the world and even him/herself. The alienation that is caused by an impairment is similar to the one that happens because of other situations of social abuse. What affects the disabled's identity most is the loss of his/her ability to do things for him/ herself, which increases the dependency on other people. This dependency is considered as an obstruction for the disabled more than the physical injury itself because it increases the feelings of shame and frustration because of their needs. These conflicting feelings of alienation and loss of one's own identity are discussed in Lisa Genova's novel Left Neglected and Jean Dominique Bauby's disability memoir The Diving Bell. They show how a sudden accident causes a life-changing collision and how

(Loss of Identity and Alienation in Jean Dominique ...) Ghady Hamdy 
high- achieving people struggle to rebuild themselves and their lives.

\section{Works Cited}

Bauby, Jean Dominique. The Diving Bell and the Butterfly. Vintage Books, 1997.

Dudzinski, Denise M. "The Diving Bell Meets the Butterfly: Identity Lost and Re-Membered." Theoretical Medicine and

(Loss of Identity and Alienation in Jean Dominique ...) Ghady Hamdy 
Bioethics, vol.22, no.1, 2001, pp. 33-46. Springer, https://link.springer.com/article/10.1023/A:1009981213630.

Galvin, Rose D.," Researching the Disabled Identity: contextualising the identity transformations which accompany the onset of impairment." Sociology of Health \& Illness, vol. 27, no. 3, 2005, pp. 393- 413. Wiley Online Library,

https://onlinelibrary.wiley.com/doi/epdf/10.1111/j.1467-

9566.2005.00448.x

Genova, Lisa. Left Neglected. Gallery Books, 2011.

Kent, Ray D. "Insights from Memoirs of Illness and Disability."ASHA,1998,pp.22-

25.https://www.asha.org/uploadedFiles/Sum98ashamag1.pdf Mathiasen, Helle. "Mind Over Body: The Diving Bell and the Butterfly." The American journal of medicine, vol. 121, no. 9, 2008, pp. 829. PlumX Metrics, https://doi.org/10.1016/j.amjmed.2008.05.033

Romeis, James C. "Alienation as a Consequence of Disability: Contradictory Evidence and its Interpretations." Sociology of Health and Illness, vol.5, no.1, 1983.

onlinelibrary.wiley.com/doi/10.1111/1467-9566.ep11340052/pdf Thompson, Hannah. "De simple malade j'etais devenu un handicape": Interrogating the Construction of 'Disability' in Jean Dominique Bauby's Le scaphandre et le papillon." L'esprit Createur, vol.56, no.2, 2016, pp.79-92. Project Muse,

https://muse.jhu.edu/article/622002/summary

Wilson, Barbara A, et. al. "A Case Study of Locked-inSyndrome: Psychological and Personal Perspectives." Brain Injury, vol.25, no.5, 2011, pp. 526-538. Taylor \& Francis Online, 


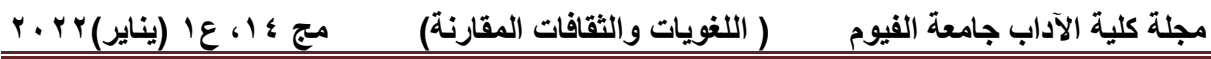

https://www.tandfonline.com/doi/abs/10.3109/02699052.2011.56 8034? journalCode $=$ ibij20

(Loss of Identity and Alienation in Jean Dominique ...) Ghady Hamdy 


\section{ملخص}

إن الإعاقة، سواء كانت تدريجية أو صادمة ،خلقية أو عارضة، يمكن أن يكون لها تأثير على قيم المـرء ونظرتـه للعـالم من حولـه. ويمكن أن تتسبب الإعاقـة في تولد شـعور مـن الاغتراب وفقدان الهويـة في داخل الثـخص ذي الإعاقـة. إن شـور الاغتراب النـاجم عن

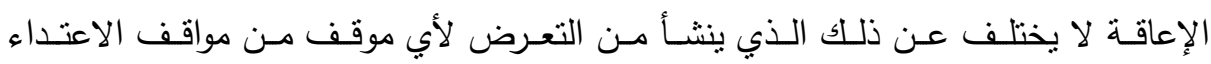

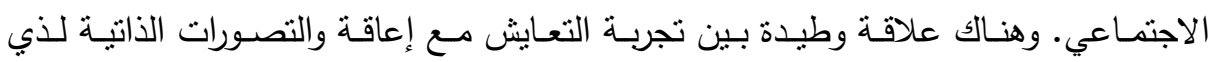
الإعاقـة، حيث تسـاعد هذه التجربـة في تكوين هويتهم. وقد تمـت مناقنــة هذه المشـاعر المتضـاربة من الاغتراب وفقدان الهويـة الثخصية في روايـة "قناع الغوص" لجان دومينيك كيك بوبي و "الإهمال النصفي" لليزا جينوفا. تتاقش كلتا الروايتين كيف يتسبب حادث مفاجئ في

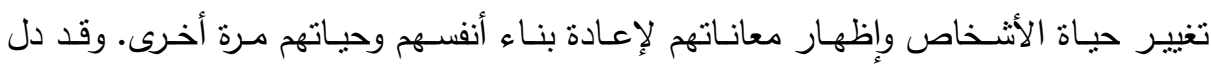
استخدام هذه الاستراتيجية للسرد على أن التجربة الثخصبة لذوي الاحتباجات الخاصـة لها لهاء

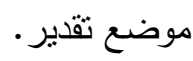

الكلمــات المفتاحيـة: الاراســات الخاصــة بـذوي الإعاقـة ، عــم الـنفس ، فقـــان الهويـة ، والاغتراب. 